\title{
Seasonal variations and spatial distribution of particulate matter emissions from a ventilated laying hen house in Northeast China
}

\author{
Li Guo ${ }^{1,2}$, Dongsen Zhao ${ }^{1,2}$, Bo Zhao ${ }^{1,2}$, Shuli Ma ${ }^{1,2}$, Xiaolin $\mathrm{Liu}^{3}$, Mo Li ${ }^{1,2}$, Xin Liu ${ }^{1,2 *}$ \\ (1. College of Biological and Agricultural Engineering, Jilin University, Changchun 130022, China; \\ 2. Key Laboratory of Bionic Engineering, Ministry of Education of China, Jilin University, Changchun 130022, China; \\ 3. China Architecture Design Group, Beijing 100044, China)
}

\begin{abstract}
With the development of concentrated animal feeding operations in China, the air pollution problem has drawn widespread public attention. Residents living near farms are suffering from the emissions of particulate matter (PM) and odors. However, scientific data on the characteristics of these emissions are limited to the establishment and evaluation of mitigation strategies in China. This study was conducted to provide fundamental information on the concentrations of PM inside and outside a typical ventilated laying hen house in northeastern China. The results showed that outdoor PM concentrations of this laying hen house did not meet the requirements of the environmental quality standard of China's livestock and poultry farms in the two days out of six sampling days in summer, while indoor PM concentrations met the environmental requirements during this study. The indoor and outdoor PM concentrations were highly correlated in summer, and over $60 \%$ of particles indoor were emitted outside via mechanical ventilation. There were more fine particles dominated both inside and outside of the laying hen house. Besides, twelve and nine elements were measured from the PM sources inside and outside laying hen house, respectively. PM control strategies may be adjusted based on the status of exhaust fans, the ages of laying hens, atmospheric conditions, and routine house management to well reduce PM emissions and improve control efficiency.
\end{abstract}

Keywords: particulate matter, ventilated laying hen house, air emission, animal feeding operation DOI: $10.25165 /$ j.ijabe.20201303.5111

Citation: Guo L, Zhao D S, Zhao B, Ma S L, Liu X L, Li M, et al. Seasonal variations and spatial distribution of particulate matter emissions from a ventilated laying hen house in Northeast China. Int J Agric \& Biol Eng, 2020; 13(3): 57-63.

\section{Introduction}

The high concentration of particulate matter (PM) can affect environmental sustainability as well as human and animal health and well-being ${ }^{[1]}$. Long-term exposure to air pollutants increased the risk of lung disease, mortality, and respiratory system or heart failure hospitalization ${ }^{[2-5]}$. The air pollution emitted from livestock and poultry breeding industry contained high levels of particulate matter, endotoxin, toxic gases, and other microbial components ${ }^{[6]}$. The PM concentration in livestock and poultry houses was 10-200 times higher than in other indoor environments ${ }^{[6]}$. Carrying odorous compound, bacterial and virus, the PM from poultry houses may be dispersed to the environment and surrounding communities ${ }^{[1,7]}$. Residents near poultry farms were more likely to develop pneumonia ${ }^{[8]}$. Patients with chronic obstructive pulmonary disease were at increased risk of worsening the disease by exposure to the emissions from livestock farms ${ }^{[9]}$.

Received date: 2019-04-25 Accepted date: 2020-03-31

Biographies: Li Guo, PhD, Associate Professor, research interest: air pollution control, Email: liguo2012@jlu.edu.cn; Dongsen Zhao, Master candidate, research interest: air pollution control, Email: zhaods17@mails.jlu.edu.cn; Bo Zhao, Master student, research interest: air pollution control, Email: zhaob18@mails.jlu.edu.cn; Shuli Ma, Master student, research interest: air pollution control, Email: mas116@mails.jlu.edu.cn; Xiaolin Liu, Master, Senior Engineer, research interest: ecology and environment, Email: liuxiaolin@cadg.cn; Mo $\mathbf{L i}, \mathrm{PhD}$, Associate Professor, research interest: agriculture engineering, Email: moli@jlu.edu.cn.

*Corresponding author: Xin Liu, PhD, Assistant Professor, research interest: air pollution control in agriculture. College of Biological and Agricultural Engineering, Jilin University, 5988 Renmin Street, Changchun 130022, China. Tel: +86-431-8509-5760, Email: 1x2017@jlu.edu.cn.
It was indicated that PM concentration in a poultry house was higher than that in pigsty and dairy farms ${ }^{[10]}$. The average number of microbiota and gram-negative bacteria in domestic poultry houses was 2.5 times and 1.3 times higher than that in pig houses, respectively ${ }^{[11]}$. Excessive PM affected the feeding, weight gain and production performance of chickens, led to various respiratory diseases $^{[12]}$. Moreover, higher PM concentration determined a higher concentration of endotoxin ${ }^{[13]}$. Fine particles in poultry houses had long residence time and can be transported over long distances $^{[14]}$. Once inhaled, fine particles can be trapped in the respiratory system ${ }^{[15]}$. Housing and climate conditions influenced the state of poultry by affecting the intake and utilization of food, which affected the PM concentrations in chicken coops ${ }^{[16,17]}$.

Currently, for the livestock and poultry industry, the data on PM emission sources, levels, sampling methods, simulation evaluation and estimation, and mitigation strategies are available mainly from developed countries. It cannot be directly used to reflect the status of PM emission from livestock and poultry in China since there are great differences in the farming systems between China and developed countries ${ }^{[18]}$. Compared to developed countries, improving pollutant treatment facilities, environmental regulation of livestock and poultry houses is still demanded in China ${ }^{[19]}$. Nevertheless, there are few detailed studies on seasonal variations and spatial distribution of PM from poultry houses in China, which may contribute to constructing strategies to control air pollution from poultry breeding. Especially in northeastern China, the production of livestock and poultry pollutants was significantly higher than that in other regions of China, and public attention on livestock and poultry environment is low ${ }^{[20]}$. It is necessary to conduct experiments to investigate the current situation of livestock and poultry pollution 
and provide technical support for formulating policies, standards, and guidelines related to environmental protection.

In this study, PM inside and outside a ventilated laying hen house was sampled to investigate the influencing factors of PM emissions and their characteristics in spring and summer. These results will contribute to optimizing the management of poultry farming to reduce the adverse effects of PM on the growth and production of laying hens as well as the ambient environment.

\section{Materials and methods}

\subsection{Experimental site}

One typical ventilated poultry house, located in the suburban area of Changchun $\left(43.9^{\circ} \mathrm{N}, 125.3^{\circ} \mathrm{W}\right)$, China, was selected as the experimental site for monitoring PM emissions. The poultry house was $53 \mathrm{~m} \times 10 \mathrm{~m} \times 4 \mathrm{~m}$ (length $\times$ width $\times$ height) and east-west oriented, equipped with four exhaust fans (Model DS-1380, Lanhao Ventilation and Cooling Equipment Company, Dongguan, with a diameter of $1.38 \mathrm{~m}$ ) on the west sidewall with a spacing of $0.9 \mathrm{~m}$ between adjacent edges (Figure 1). Besides, it had windows on the north and south side. Fans and windows were regularly closed in winter and spring in order to keep the house warm. Only when the indoor temperature was above $25^{\circ} \mathrm{C}$, would the fans be turned on. In this study, these fans worked at all sampling times in summer and about 4 hours of each sampling day in spring. The house had also two wet curtains installed in the east-side wall in case the temperature was too high to reduce the heat stress of animals $^{[21]}$. There were 4 cages in the house, each of which had 3 layers equipped with an automatic feeder and a nipple drinking water dispenser. The laying hen dung was cleared with a mechanical scraper. Workers collected eggs at 8:30, and the feeding time was 10:00 and 16:00 in one day.
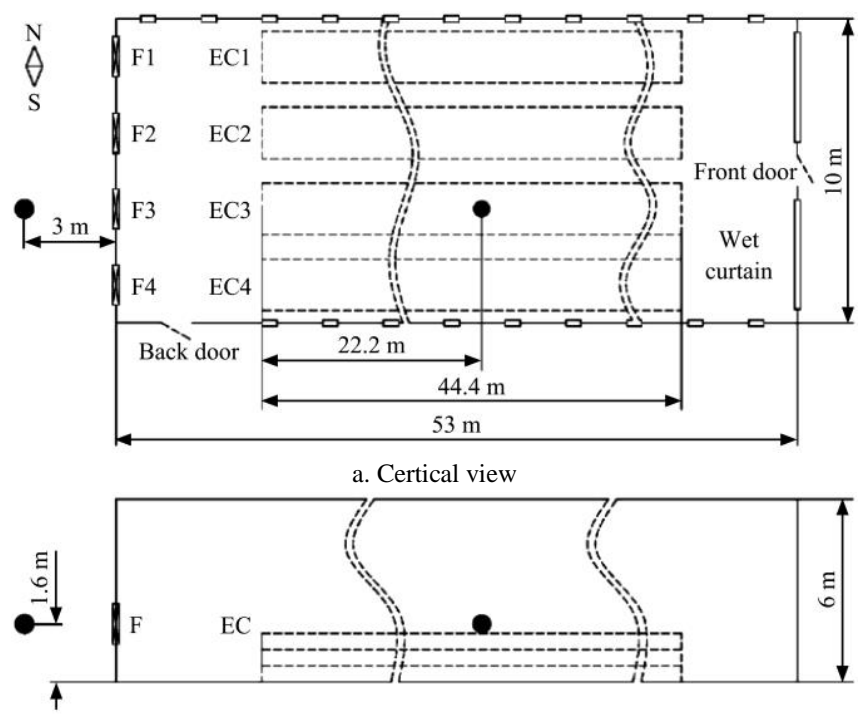

b. Front view

Monitoring point; $\square$ Windows; $\mathrm{F}=\mathrm{Fan} ; \mathrm{EC}=$ Egg cage

Figure 1 Schematic diagram of monitoring points inside and outside laying hen house (not to scale)

\subsection{Field sampling}

The field sampling was concentrated in two typical seasons of spring ( $3 d$ in 2016 and $4 d$ in 2017) and summer (6 d in 2016). In order to reduce the impact of the natural environment, the sampling campaign was chosen in the days with no rain and breezes. There were 8000 laying hens of Hy-Line Variety Brown with the age of 10-74 $\mathrm{d}$ in 2016, and 7800 with the age of 54-76 d in 2017. It was reported that the PM concentration inside the poultry house is higher in the daytime than that at night ${ }^{[22]}$. Therefore, the sampling time was set between 10:00 and 16:00 daily with potential high PM concentration. Particle concentration, ambient humidity and temperature were synchronously monitored at the same locations, as shown in Figure 1. In addition, to investigate the PM sources, dust particles accumulated on the ground of the house and the blades of ventilation fans were collected in summer for analyzing elements composition of PM.

Real-time particle concentrations were monitored using DustTruck $^{\mathrm{TM}}$ DRX (Model 8533, TSI Incorporated, U.S.A.), which can simultaneously monitor size segregated mass fractions of $\mathrm{PM}_{2.5}$ and $\mathrm{PM}_{10}$ (particulate matter with an aerodynamic diameter of $2.5 \mu \mathrm{m}$ and $10 \mu \mathrm{m}$ or less, respectively) as well as for TSP (total suspended particulate $)^{[23]}$. The sampling range is 0.001 $150 \mathrm{mg} / \mathrm{m}^{3}$ with a $\pm 0.1 \%$ resolution. Before each test, the instruments were regularly checked and calibrated with its zero filters $^{[24]}$. Moreover, AOSONG monitor (Model AH200, AOSONG, Guangzhou, China) was used to monitor ambient temperature (range: $-40^{\circ} \mathrm{C}-80^{\circ} \mathrm{C}$; resolution: $\pm 3^{\circ} \mathrm{C}$ at $25^{\circ} \mathrm{C}$ ) and relative humidity (RH) (range: $0-99.9 \%$; resolution: $\pm 2 \%$ ). During each test, the sampling data was recorded per $1 \mathrm{~min}$. In addition, two anemometers were originally set up with these two aerosol monitors to measure the wind speed. However, the data was not able to be collected because of the data logger malfunction during some of these sampling days. Therefore the rest of wind speed data was not reported in this study though it might be one of the major factors affecting PM emissions. Based on the estimation from the literature ${ }^{[25-27]}$ and our previous tests on-site, the wind speed from the fan should be around 3-6 m/s. The components of particles were analyzed by using an energy dispersive x-ray detector (EDX) (Model INCA, Oxford instrument, UK).

\subsection{Data analysis}

The daily average PM concentrations were reported with standard error (SE). Since PM ratios may reflect particle size distribution and provide an estimation of fine PM concentrations using available TSP or $\mathrm{PM}_{10}$ data, the percentage of segregated PM $\left(\mathrm{PM}_{10}\right.$-TSP, $\mathrm{PM}_{2.5}-\mathrm{PM}_{10}$, and $\left.\mathrm{PM}_{2.5}\right)$ in TSP were calculated and provided in this study, such as $\mathrm{PM}_{10}$-TSP means the percentage of the concentration difference of TSP and $\mathrm{PM}_{10}$ divided by the concentration of TSP, i.e. $\left(\mathrm{TSP}-\mathrm{PM}_{10}\right) \times 100 / \mathrm{TSP}, \%^{[28,29]}$. The ratios of indoor to outdoor $\mathrm{PM}_{2.5}, \mathrm{PM}_{10}$ and TSP concentration were also given, which can reflect, to some extent, the amount of PM transmitted from the laying hen house. Statistical analysis on PM concentrations at two sampling points was calculated with a $1 \%$ level of significance based on $t$-Test (Paired Two Sample for Means). The matrices of correlation coefficients of indoor and outdoor PM concentrations, PM concentrations and temperature, PM concentrations and relative humidity were analyzed using SPSS (IBM, USA).

\section{Results and discussion}

\subsection{Particle concentration}

The daily mean concentration of indoor $\mathrm{PM}_{2.5}$ had a range of $0.067-0.609 \mathrm{mg} / \mathrm{m}^{3}$ with averages of $0.118 \pm 0.082 \mathrm{mg} / \mathrm{m}^{3}$ in spring $2016,0.342 \pm 0.173 \mathrm{mg} / \mathrm{m}^{3}$ in summer 2016 , and $0.289 \pm 0.174 \mathrm{mg} / \mathrm{m}^{3}$ in spring 2017. Indoor $\mathrm{PM}_{10}$ concentration had a range of $0.118-1.145 \mathrm{mg} / \mathrm{m}^{3}$ with averages of $0.213 \pm 0.158 \mathrm{mg} / \mathrm{m}^{3}$ in spring $2016,0.596 \pm 0.340 \mathrm{mg} / \mathrm{m}^{3}$ in summer 2016 , and $0.534 \pm 0.242 \mathrm{mg} / \mathrm{m}^{3}$ in spring 2017. Indoor TSP concentration had a range of $0.168-1.585 \mathrm{mg} / \mathrm{m}^{3}$ with averages of $0.295 \pm 0.229 \mathrm{mg} / \mathrm{m}^{3}$ in spring $2016,0.814 \pm 0.490 \mathrm{mg} / \mathrm{m}^{3}$ in summer 2016 , and $0.819 \pm 0.383 \mathrm{mg} / \mathrm{m}^{3}$ 
in spring 2017, as shown in Figure 2a. It indicates that the indoor PM concentration during our sampling days met the requirements of the environmental quality standard of China's livestock and poultry farms (EQSF, the number of laying hens raised at the site exceeds 5000), which requires $\mathrm{PM}_{10}$ and TSP concentration inside the house area should be controlled to be less than $4 \mathrm{mg} / \mathrm{m}^{3}$ and $8 \mathrm{mg} / \mathrm{m}^{3}$, respectively ${ }^{[30]}$.

The daily mean concentration of outdoor $\mathrm{PM}_{2.5}$ had a range of $0.026-0.364 \mathrm{mg} / \mathrm{m}^{3}$ with averages of $0.041 \pm 0.020 \mathrm{mg} / \mathrm{m}^{3}$ in spring $2016,0.205 \pm 0.098 \mathrm{mg} / \mathrm{m}^{3}$ in summer 2016, and $0.071 \pm 0.059 \mathrm{mg} / \mathrm{m}^{3}$ in spring 2017. Outdoor $\mathrm{PM}_{10}$ concentration had a range of $0.038-0.720 \mathrm{mg} / \mathrm{m}^{3}$ with averages of $0.054 \pm 0.024 \mathrm{mg} / \mathrm{m}^{3}$ in spring $2016,0.363 \pm 0.214 \mathrm{mg} / \mathrm{m}^{3}$ in summer 2016 , and $0.079 \pm 0.060 \mathrm{mg} / \mathrm{m}^{3}$ in spring 2017. Outdoor TSP concentration had a range of $0.049-1.049 \mathrm{mg} / \mathrm{m}^{3}$ with averages of $0.070 \pm 0.029 \mathrm{mg} / \mathrm{m}^{3}$ in spring $2016,0.518 \pm 0.322 \mathrm{mg} / \mathrm{m}^{3}$ in summer 2016 , and $0.085 \pm 0.062 \mathrm{mg} / \mathrm{m}^{3}$ in spring 2017, as shown in Figure 2b. The results show that there were $4 \mathrm{~d}$ out of $6 \mathrm{~d}$ of sampling time in summer that the outdoor PM concentration met the requirements of EQSF, which requires $\mathrm{PM}_{10}$ and TSP concentration in the buffer zone (within $500 \mathrm{~m}$ around the farm) should be controlled to be less than $0.5 \mathrm{mg} / \mathrm{m}^{3}$ and $1 \mathrm{mg} / \mathrm{m}^{3}$, respectively ${ }^{[30]}$.
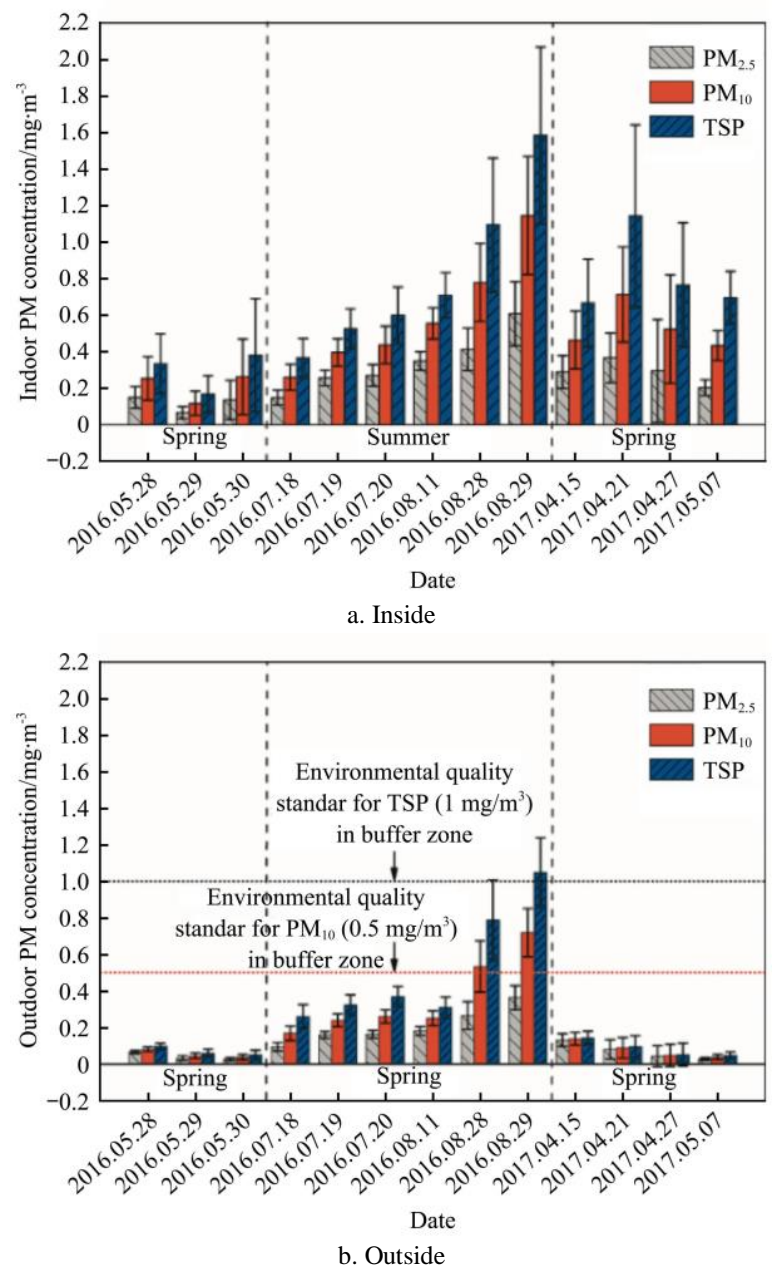

Figure 2 Concentrations of particles (a) inside and (b) outside the laying hen house

\subsection{Correlation between indoor and outdoor particulate} matter concentrations

From the matrix of correlation coefficient of indoor and outdoor PM concentrations in spring and summer (Table 1), it can be seen that all of the indoor and outdoor particle concentrations in summer were in good correlation $(p<0.01)$, yet in spring were poor. This should be caused by the ventilation fans, which exhausted PM suspended indoor to the outdoor atmosphere in summer. Another notable phenomenon observed was that the correlation between the concentration of outdoor $\mathrm{PM}_{2.5}$ and the concentration of indoor $\mathrm{PM}_{2.5}$ was the highest compared with others in spring, while the correlation between the concentration of outdoor $\mathrm{PM}_{2.5}$ and the concentration of indoor TSP was the highest compared with others in summer. It indicated that more fine particles can be emitted outside from the house and the ventilation fans brought more large particles to the outside from the laying hen house in summer. As expected, the closure of windows and exhaust fans significantly reduced the transportation of indoor particulates to outside.

Table 1 Correlation coefficients ( $r$ ) between indoor and outdoor particulate matter concentrations.

\begin{tabular}{lccccccc}
\hline & \multicolumn{3}{c}{ Outdoor PM in spring } & & \multicolumn{3}{c}{ Outdoor PM in summer } \\
\cline { 2 - 3 } \cline { 6 - 7 } & $\mathrm{PM}_{2.5}$ & $\mathrm{PM}_{10}$ & $\mathrm{TSP}$ & & $\mathrm{PM}_{2.5}$ & $\mathrm{PM}_{10}$ & TSP \\
\hline Indoor $\mathrm{PM}_{2.5}$ & 0.545 & & & $0.979^{\mathrm{a}}$ & & \\
Indoor $\mathrm{PM}_{10}$ & 0.402 & 0.341 & & $0.992^{\mathrm{a}}$ & $0.966^{\mathrm{a}}$ & \\
Indoor TSP & 0.351 & 0.290 & 0.182 & & $0.994^{\mathrm{a}}$ & $0.980^{\mathrm{a}}$ & $0.962^{\mathrm{a}}$ \\
\hline
\end{tabular}

Note: ${ }^{\text {a }}$ Correlation was significant at the 0.01 level.

\subsection{Ratio of outdoor to indoor particulate concentration}

The ratios of outdoor $\mathrm{PM}_{2.5}, \mathrm{PM}_{10}$ and TSP concentration to the corresponding indoor PM, as listed in Table 2, can partly reflect the amount of particle emitted from the laying hen house to the ambient atmosphere. The larger the value is, the bigger the percentage of PM transmitted from the interior to the exterior. The results indicated that during summer sampling time, more than $60 \%$ of particles from the poultry house had been transported to the outside atmosphere, and quantities of coarse particles were larger in the PM emitted from the house. On the contrary, the ratios became very small, especially in spring 2017, and the outdoor TSP concentration was only $10 \%$ of indoor TSP concentration when all of the fans were closed. Moreover, relatively more fine particles emitted from the poultry house. These findings were consistent with the results of the above correlation analysis between the concentration of indoor and outdoor particles.

Table 2 Ratio of indoor particulate concentration to that of outdoor

\begin{tabular}{lccc}
\hline & \multicolumn{3}{c}{ Outdoor /Indoor } \\
\cline { 2 - 4 } & $\mathrm{PM}_{2.5}$ & $\mathrm{PM}_{10}$ & TSP \\
\hline Spring, 2016 & $35 \%$ & $25 \%$ & $24 \%$ \\
Summer, 2016 & $60 \%$ & $61 \%$ & $64 \%$ \\
Spring, 2017 & $25 \%$ & $15 \%$ & $10 \%$ \\
\hline
\end{tabular}

3.4 Particle size distribution

Indoor and outdoor percentages of different sized PM in the TSP, presented in Figure 3, indicated that $\mathrm{PM}_{2.5}$ was relatively high in TSP both in spring and summer. The outdoor percentage of $\mathrm{PM}_{2.5} / \mathrm{TSP}$ in spring was almost always greater than 50\%. The highest percentage $\left(90.5 \%\right.$ ) of $\mathrm{PM}_{2.5} / \mathrm{TSP}$ occurred in spring 2017. These indicated that there were more fine particles dominated in and out of the laying hen house. Compared to indoor particle size distribution, the outdoor percentages of different sized PM in the TSP had greater variation. In the last two sampling days of summer 2016, the ratio of $\mathrm{PM}_{2.5} / \mathrm{TSP}$ decreased. This may be caused by high PM concentration during these two days and more large-diameter particles were exhaled by the fans. However, fine particles had very high percentages in spring. This may be attributed to less coarse particles emitted from the house. 

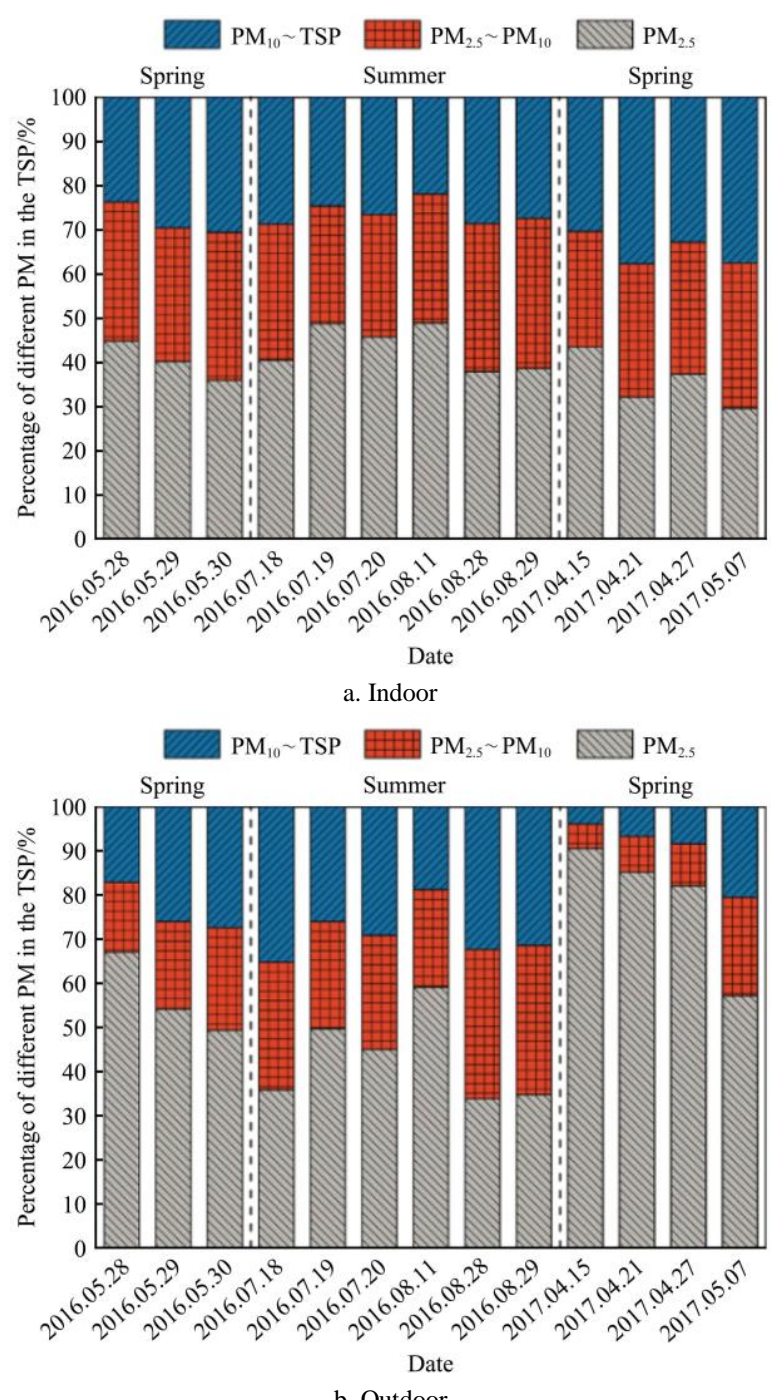

Figure 3 Percentages of different PM in the TSP: (a) indoor, and (b) outdoor

\subsection{Particle composition}

The data from EDX tests, as shown in Table 3, indicated that there were 12 different elements (C, O, Na, Mg, Al, Si, P, S, Cl, K, $\mathrm{Ca}, \mathrm{Fe}$ ) in the indoor PM sources and only 9 of them were detected outside of the house. The reason that the elements of $\mathrm{Na}, \mathrm{P}, \mathrm{Cl}$ were not found may be attributed to 1) the house was cleaned every morning, and some of the indoor dust including these elements was cleared away; 2) some coarse particles containing these elements settled down before they were transported to outside.

Indoor and outdoor particles had a very high content of $\mathrm{C}, \mathrm{O}$ (Table 3). Particulates emitted from laying hen house were mainly from feathers, epidermal debris, feed particles, feces, and so on ${ }^{[31]}$. These contained proteins, which were mainly composed of $\mathrm{C}, \mathrm{H}, \mathrm{O}$, and N. However, elements of indoor and outdoor PMs did not have $\mathrm{N}$. One possible reason was that the content of $\mathrm{N}$ was too little to be detected in samples. The results also showed that indoor PM had higher relative levels of $\mathrm{Ca}$, and $\mathrm{Si}$ than outside PM. It is because these two elements in the feed were high, and the activity of laying hens caused plenty of feed falling near the indoor sample collection point $^{[4]}$. The reason for the highest content of Ca except for $\mathrm{C}$ and $\mathrm{O}$ in the laying hen house may be due to the high $\mathrm{Ca}$ content in the feed. Besides, the particles outside the house had a higher content of $\mathrm{C}, \mathrm{S}$, and Fe compared with that from the indoor PM. The mass percentage of $\mathrm{Fe}$ outside the house was almost two times that of the inside, this may be because some particles from the fan blades might be mixed with the samples.

Table 3 Mean relative element content of collected particles $\%$

\begin{tabular}{ccccc}
\hline \multirow{2}{*}{ Elements } & \multicolumn{2}{c}{ Indoor } & \multicolumn{2}{c}{ Outdoor } \\
\cline { 2 - 5 } \cline { 3 - 5 } & Weight & Atomic & Weight & Atomic \\
\hline $\mathrm{C}$ & 44.19 & 54.76 & 55.94 & 64.44 \\
$\mathrm{O}$ & 41.51 & 38.61 & 38.76 & 33.52 \\
$\mathrm{Na}$ & 1.37 & 0.89 & - & - \\
$\mathrm{Mg}$ & 1.23 & 0.76 & 0.37 & 0.21 \\
$\mathrm{Al}$ & 0.49 & 0.27 & 0.44 & 0.23 \\
$\mathrm{Si}$ & 1.49 & 0.79 & 0.66 & 0.32 \\
$\mathrm{P}$ & 2.65 & 1.27 & - & - \\
$\mathrm{S}$ & 0.61 & 0.28 & 0.72 & 0.31 \\
$\mathrm{Cl}$ & 0.58 & 0.24 & - & - \\
$\mathrm{K}$ & 1.11 & 0.42 & 0.85 & 0.30 \\
$\mathrm{Ca}$ & 4.14 & 1.54 & 1.13 & 0.39 \\
$\mathrm{Fe}$ & 0.63 & 0.17 & 1.13 & 0.28 \\
$\mathrm{Totals}$ & 100.00 & - & 100.00 & - \\
\hline
\end{tabular}

\subsection{Factors affecting particulate emissions}

The concentrations of indoor PM gradually increased from spring to summer in 2016 as shown in Figure 2, and the PM concentrations in spring 2017 were greater than that in 2016. These variations might be caused by the positive correlation between dust concentration and poultry age ${ }^{[4]}$ since the laying hens in spring 2016 was the same batch of that in summer and their age was much younger, and the age of laying hens in 2017 was similar with that in summer 2016. Moreover, both in spring and summer, indoor PM concentrations were higher than those outside. The greatest difference occurred in spring 2017 and the differences were lesser in spring 2016. It should be mainly caused by the closure of the exhaust fans in spring which resulted in less particulate emitted to outside, and the age of lay hens in spring of 2017 which was older and active to produce more particles. The minimum difference of indoor and outdoor PM concentrations appeared in the summer of 2016, which indicated that the working of the ventilation fans significantly enhanced the transmission and diffusion of particles to the atmosphere. Therefore, the outside PM concentrations might be a higher possibility to exceed the related standard. These results indicated that for well control PM emissions from the poultry house, farmers may adopt and adjust PM control strategies: 1) with the age of laying hens, enhancing control intensity and/or frequency when they become older; 2) with the status of exhaust fans, applying PM mitigation methods to reduce ambient environmental impaction when the fans are turned on.

In addition, the following factors may also cause a variation of PM emissions.

3.6.1 Temperature and relative humidity

The indoor and outdoor daily average temperature in summer 2016 ranged from $27.6^{\circ} \mathrm{C}$ to $29.7^{\circ} \mathrm{C}$ and $26.9^{\circ} \mathrm{C}$ to $32.5^{\circ} \mathrm{C}$, respectively, while daily average temperatures in spring 2017 were relatively low for both indoors $\left(20.5^{\circ} \mathrm{C}\right.$ to $\left.23.3^{\circ} \mathrm{C}\right)$ and outdoors $\left(22.8^{\circ} \mathrm{C}\right.$ to $28.3^{\circ} \mathrm{C}$ ) (Figure 4 ). In summer 2016 , the daily average RH inside and outside the laying hen house was $39.0 \%$ to $77.7 \%$ and $40.4 \%$ to $64.1 \%$, respectively. For laying hens, the upper limit of $\mathrm{RH}$ in China's environmental quality standard is $75 \%{ }^{[30]}$. The indoor RH during the study was able to meet this standard almost every day in summer. Owing to the dry and windy spring in Changchun, the daily average RH was at a low level for both indoors (19.2\% to $31.0 \%)$ and outdoors (12.3\% to $17.5 \%)$. 


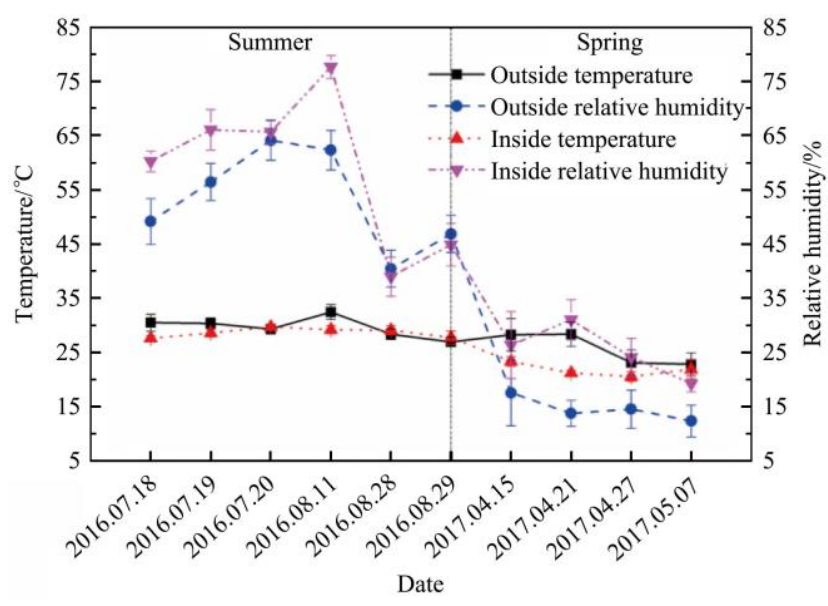

Figure 4 Variety of temperature and relative humidity during the test

Correlation coefficients between PM concentrations and temperature and RH (Table 4) showed that PM concentration outside the house was significantly and positively correlated with temperature and RH at $p<0.01$ level in spring. It indicated that the change of temperature and $\mathrm{RH}$ in spring had a significant impact on the outdoor PM concentration. Moreover, the correlations between $\mathrm{PM}_{2.5}, \mathrm{PM}_{10}$ and TSP concentrations and temperature were basically the same. Therefore, the temperature had a similar effect on the concentration of outdoor PMs with different sizes in spring. The correlation between indoor $\mathrm{PM}_{2.5}$ concentration and temperature in spring was not statistically significant. Indoor PM concentrations in spring had little correlation with temperature (excluding $\mathrm{PM}_{2.5}$ ) and were positively correlated with RH $(p<0.01)$. It can be seen that the increase of RH in spring did not reduce PM concentrations. From reference [1], only if the RH was large enough, the PM concentrations may be reduced due to the high water content of the environment. As can be seen from Figure 4, the RH was relatively

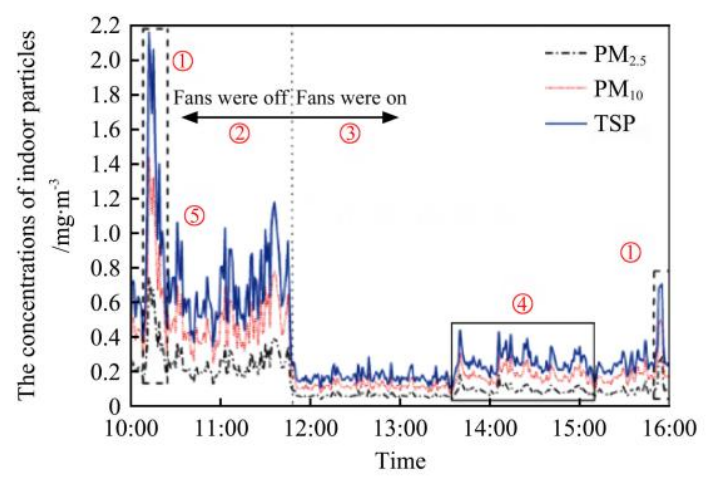

a. Indoor PM concentration on May $30^{\text {th }}, 2016$

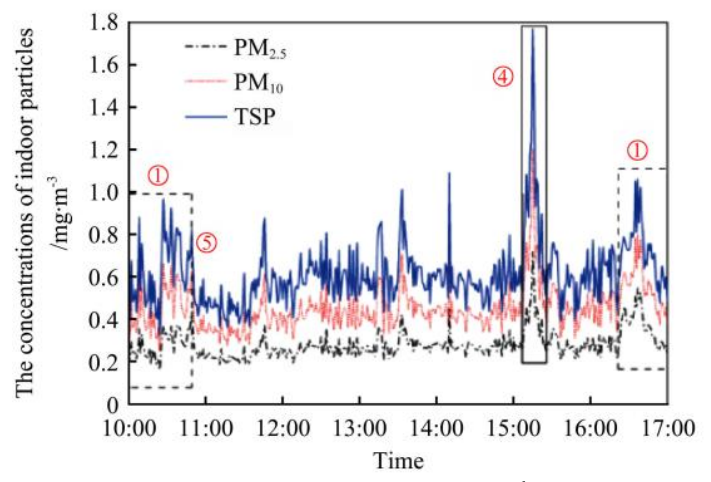

c. Indoor PM concentration on July $20^{\text {th }}, 2016$ low in the spring, so the particle concentration didn't rise as its value increased.

Table 4 Correlation coefficients between particulate matter concentrations and temperature and relative humidity

\begin{tabular}{|c|c|c|c|c|c|c|}
\hline & \multicolumn{3}{|c|}{ Outdoor PM } & \multicolumn{3}{|c|}{ Indoor PM } \\
\hline & $\mathrm{PM}_{2.5}$ & $\mathrm{PM}_{10}$ & TSP & $\mathrm{PM}_{2.5}$ & $\mathrm{PM}_{10}$ & TSP \\
\hline $\begin{array}{l}\text { Temperature in } \\
\text { spring }\end{array}$ & $0.567^{\mathrm{b}}$ & $0.563^{b}$ & $0.533^{b}$ & -0.123 & $-0.207^{b}$ & $-0.205^{b}$ \\
\hline $\begin{array}{l}\text { Relative humidity } \\
\text { in spring }\end{array}$ & $0.499^{b}$ & $0.512^{b}$ & $0.543^{b}$ & $0.337^{b}$ & $0.465^{b}$ & $0.503^{b}$ \\
\hline $\begin{array}{l}\text { Temperature in } \\
\text { summer }\end{array}$ & $-0.133^{b}$ & $-0.284^{b}$ & $-0.366^{\mathrm{b}}$ & 0.007 & -0.045 & $-0.055^{b}$ \\
\hline $\begin{array}{l}\text { Relative humidity } \\
\text { in summer }\end{array}$ & -0.003 & $-0.186^{b}$ & $-0.263^{b}$ & -0.383 & -0.491 & -0.514 \\
\hline
\end{tabular}

Note: ${ }^{\mathrm{b}}$ Correlation was significant at the 0.01 level.

In summer, the correlations between indoor $\mathrm{PM}_{2.5}$ concentration and temperature, outdoor $\mathrm{PM}_{2.5}$ concentration and $\mathrm{RH}$ were not statistically significant. During this period, indoor concentrations of $\mathrm{PM}_{10}$, TSP and outdoor concentrations of PMs had little correlation with temperature, and the correlations were negative. Moreover, outdoor concentrations of $\mathrm{PM}_{10}$, TSP and indoor PM concentrations were negatively correlated with RH. Therefore, an appropriate increase of RH in summer contributed to decreasing PM concentrations. By comparing the correlation coefficient between the concentration of different sized particles and $\mathrm{RH}$, it can be found that RH had a stronger effect on the settlement of particles with the larger size.

3.6.2 Factors affecting the diurnal change of particulate matter

To find out the factors influencing daily variation of PM concentration inside and outside the laying hen house, two typical dates (May 30 of 2016 and July 20 of 2017) which had a great variation of PM concentrations were selected to further check the reasons for their diurnal PM changes.

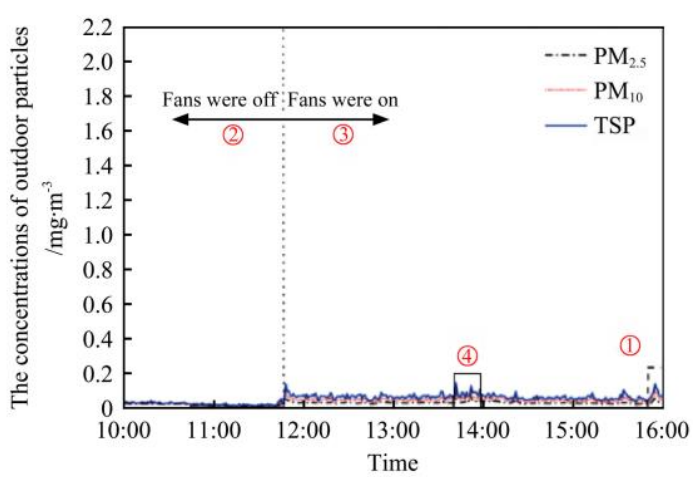

b. Outdoor PM concentration on May $30^{\text {th }}, 2016$

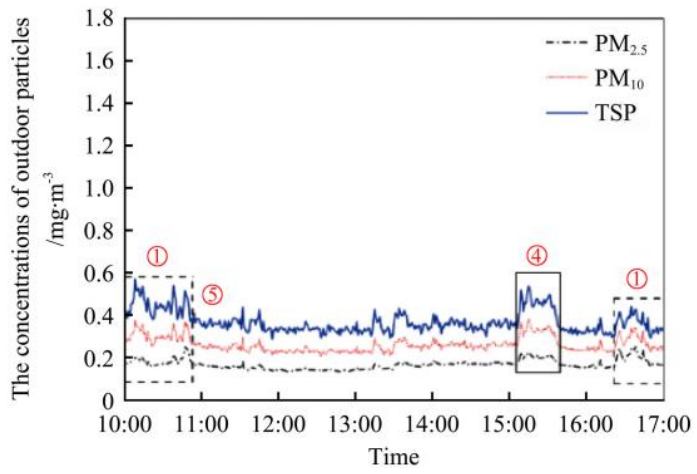

d. Outdoor PM concentration on July $20^{\text {th }}, 2016$

Note: $1=$ Feeding; $2=$ Fans off; $3=$ Fans on; 4= Staff working; $5=$ Activity decrease of the laying hens.

Figure 5 Diurnal variation of PM concentrations inside and outside the laying henhouse: 
As we can see from Figure 5a, on May 30 of 2016, the highest indoor PM concentration appeared at 10:15, which was attributed to the feeding operation. When the automatic feeding machine passed the indoor monitoring point, the process of unloading feed would levitate the PM and also increase the activity of the laying hens nearby, generating more suspended dust. With the completion of feeding, the activity of layers gradually reduced, resulting in the PM decrease in the house. At noon, to decrease the temperature in the house, the exhaust fan was turned on. Then, the indoor concentration of the particles was obviously reduced and the outdoor PM concentration increased. From 13:35 to 15:10, the PM concentrations in the house fluctuated, which might be attributed to the working of staff and also caused the fluctuation of outdoor PM concentrations between 13:45 and 13:58. The short fluctuation time between 13:58 and 15:10 may be due to that the staff worked quite close to the monitoring equipment. At approximately 16:00, indoor and outdoor PM concentrations tended to increase during the feeding. On July 20, the exhaust fan was on during the whole sampling time, and the variation trend of indoor and outdoor PM concentration was basically the same. It is clear from Figure $5 \mathrm{~d}$ that the PM concentration on July 20 also fluctuated correspondingly due to the effects of feeding, the activity of laying hens and staff working.

Many factors might had caused the change of PM concentrations inside and outside the laying hen house, including feeding, egg collection, cleaning, working state of the fans, age and activity of the chicken, temperature and relative humidity, etc. Although feeding and cleaning of the chicken coop were unavoidable, the state of the fans, indoor temperature and RH can be changed without affecting the health and the rate of egg production to reduce PM suspension and transmission.

\section{Conclusions}

To investigate the emission status of $\mathrm{PM}_{2.5}, \mathrm{PM}_{10}$ and TSP from the typical laying hen house in the northeastern area of China, the PM concentrations inside and outside a laying hen house in Changchun, China, were monitored and the potential factors affected the variation of PM concentration were analyzed. The following conclusions were drawn from this study.

1) During this study, indoor PM concentrations in the laying hen house met the requirements of the environmental quality standard of China's livestock and poultry farms. However, in two days out of six sampling days in summer with exhaust fans working, outdoor $\mathrm{PM}$ concentration did not meet the requirements of the standard for a buffer zone.

2) The particle concentrations of indoor and outdoor were highly correlated in summer, and more than $60 \%$ of indoor PM may be transported to the outdoor environment. In addition, there were more fine particles dominated both inside and outside of the laying hen house; there were 12 different elements found in the indoor PM sources, and three of them were not detected in the outdoor particle sources.

3) The exhaust fans, age of laying hens, ambient temperature, relative humidity, feeding, house cleaning and egg collection all had influenced on PM concentrations. PM control strategies may be adjusted based on these factors to well reduce PM emissions and improve control efficiency.

\section{Acknowledgments}

This study was supported by the National Natural Science Foundation of China (51575228 and 41501510), and the Research
Foundation of Science and Technology of Jilin Province of China (20190302040GX and 20180520204JH). We would like to thank Mr. Chun Wang and Ziyang Wang for their helpful assistance in experiments and data collection.

\section{[References]}

[1] Cambra-López M, Aarnink A J A, Zhao Y, Calvet S, Torres A G Airborne particulate matter from livestock production systems: A review of an air pollution problem. Environmental Pollution, 2010; 158(1): 1-17.

[2] Etchie T O, Sivanesan S, Adewuyi G O, Krishnamurthi K, Rao P S, Etchie A $\mathrm{T}$, et al. The health burden and economic costs averted by ambient $\mathrm{pm}_{2.5}$ pollution reductions in Nagpur, India. Environment International, 2017; 102: 145-156.

[3] Brunekreef B, Holgate S T. Air pollution and health. The Lancet, 2002 360(9341): 1233-1242.

[4] Cambra-López M, Torres A G, Aarnink A J A, Ogink N W M. Source analysis of fine and coarse particulate matter from livestock houses. Atmospheric Environment, 2011; 45(3): 694-707.

[5] Quarato M, De Maria L, Gatti M, Caputi A, Mansi F, Lorusso P, et al. Air pollution and public health: a PRISMA-Compliant systematic review. Atmosphere, 2017; 8(10): 183-193.

[6] Smit L A M, Hooiveld M, Van d S B F, Opstal-Van Winden A W J, Beekhuizen $\mathrm{J}$, et al. Air pollution from livestock farms, and asthma, allergic rhinitis and COPD among neighbouring residents. Occupational and Environmental Medicine, 2014; 71(2): 134-140.

[7] Dunlop M W, Blackall P J, Stuetz R M. Odour emissions from poultry litter - A review litter properties, odour formation and odorant emissions from porous materials. Journal of Environmental Management, 2016; 177 306-319.

[8] Klous G, Smit L A M, Freidl G S, Borlée F, van der Hoek W, IJzermans C $\mathrm{J}$, et al. Pneumonia risk of people living close to goat and poultry farms-Taking GPS derived mobility patterns into account. Environment International, 2018; 115: 150-160.

[9] Wood D J. A Review of ammonia and particulate matter control strategies for poultry housing. Transactions of the ASABE, 2016; 59(1): 329-344.

[10] Winkel A, Mosquera J, Groot Koerkamp P W G, Ogink N W M, Aarnink A J A. Emissions of particulate matter from animal houses in the Netherlands. Atmospheric Environment, 2015; 111: 202-212.

[11] Bakutis B, Monstviliene E, Januskeviciene G. Analyses of airborne contamination with bacteria, endotoxins and dust in livestock barns and poultry houses. Acta Veterinaria Brno, 2004; 73(2): 283-289.

[12] Almeida S M, Pio C A, Freitas M C, Reis M A, Trancoso M A Approaching PM2.5 and PM2.5-10 source apportionment by mass balance analysis, principal component analysis and particle size distribution. Science of the Total Environment, 2006; 368(2-3): 663-674.

[13] Banhazi T M, Seedorf J, Laffrique M, Rutley D L. Identification of the risk factors for high airborne particle concentrations in broiler buildings using statistical modelling. Biosystems Engineering, 2008; 101(1): 100-110.

[14] Andersen C I, Von Essen S G, Smith L M, Spencer J, Jolie R, Donham K J Respiratory symptoms and airway obstruction in swine veterinarians: A persistent problem. American Journal of Industry Medicine, 2004; 46(4): 386-392.

[15] Jonges M, van Leuken J, Wouters I, Koch G, Meijer A, Koopmans M. Wind-Mediated spread of low-pathogenic avian influenza virus into the environment during outbreaks at commercial poultry farms. PLoS One, 2015; 10(5): e0125401. doi: 10.1371/journal.pone.0125401.

[16] Freidl G, Spruijt I T, Borlée F, Smit L A, van Gageldonk-Lafeber A B, Heederik D J, et al. Livestock-associated risk factors for pneumonia in an area of intensive animal farming in the Netherlands. PLoS One, 2017; 12(3): e0174796. doi: 10.1371/journal.pone.0174796.

[17] Kamanli S, Durmuş I, Yalçın S, Yıldırım U, Meral Ö. Effect of prenatal temperature conditioning of laying hen embryos: Hatching, live performance and response to heat and cold stress during laying period. Journal of Thermal Biology, 2015; 51(1): 96-104.

[18] Wang K Y, Dai S Y, Wang L J. Research progress on pollution and monitoring technology of particulate matter from livestock and poultry farms. Transactions of the CSAM, 2017; 48: 232-241. (In Chinese)

[19] Shi Z F, Xi L. The development trend and countermeasure of animal husbandry in the New Era. Journal of Domestic Animal Ecology, 2018; 


\section{9(6): 1-4, 33. (In Chinese)}

[20] Wang H, Xu J, Liu X, Sheng L, Zhang D, Li L, et al. Study on the pollution status and control measures for the livestock and poultry breeding industry in northeastern China. Environmental Science and Pollution Research, 2018; 25(5): 4435-4445.

[21] Kuczynski T, Blanes-Vidal V, Li B, Gates R S, de Alencar Nääs I, Moura D J, et al. Impact of global climate change on the health, welfare and productivity of intensively housed livestock. Int J Agric and Biol Eng, 2011; 4(2): 1-22.

[22] Mostafa E, Buescher W. Indoor air quality improvement from particle matters for laying hen poultry houses. Biosystems Engineering, 2011; 109(1): 22-36.

[23] Brown J S, Gordon T, Price O, Asgharian B. Thoracic and respirable particle definitions for human health risk assessment. Particle and Fibre Toxicology, 2013; 10(1): 12-12.

[24] TSI. Operation and service manual for DustTrack DRX aerosol monitor model 8533/8534/8533EP. TSI Incorporated, USA, 2014.

[25] Ni J Q, Liu S, Lopes I M, Xie Q, Zheng P, Diehl C A. Monitoring, modeling, and characterizing single-speed ventilation fans for an animal building. Building and Environment, 2017; 118: 225-233.
[26] Patterson P H, Hulet R M, Bates R M, Despot D, Wheeler E, Topper P. The potential for plants to trap emissions from farms with laying hens. 1. Ammonia. Journal of Applied Poultry Research, 2008; 17(1): 54-63.

[27] Lin X J, Cortus E, Zhang R, Jiang S, Heber A. Ventilation monitoring of broiler houses in California. Transactions of the ASABE, 2011; 54(3): 1059-1068.

[28] Gehrig R, Buchmann B. Characterising seasonal variations and spatial distribution of ambient $\mathrm{PM}_{10}$ and $\mathrm{PM}_{2.5}$ concentrations based on long-term Swiss monitoring data. Atmospheric Environment, 2003; 37(19): 2571-2580.

[29] Lall R, Kendall M, Ito K, Thurston G D. Estimation of historical annual $\mathrm{PM}_{2.5}$ exposures for health effects assessment. Atmospheric Environment, 2004; 38(31): 5217-5226.

[30] MOA (Ministry of Agriculture). MOA Standard NY/T388-1999 Environmental quality standard for the livestock and poultry farm. Swine Production, 2005; 1: 42-43. (in Chinese)

[31] Woodward C L, Park S Y, Jackson D R, Li X, Birkhold S G, Pillai S D, et al. Optimization and comparison of bacterial load and sampling time for bioaerosol detection systems in a poultry layer house. Journal of Applied Poultry Research, 2004; 13(3): 433-442. 